\title{
IMPLEMENTASI PEMBELAJARAN THINK PAIR SHARE DENGAN ASESMEN UNJUK KERJA BERBANTUAN ALAT PERAGA MATERI GEOMETRI DI SMP NEGERI 1 BABAKAN
}

\section{THE IMPLEMENTATION OF THINK PAIR SHARE LEARNING WITH PERFORMANCE ASSESSMENT ASSISTANT GEOMETRY MATERIALS TOOLS IN SMP NEGERI 1 BABAKAN}

\author{
Rivo Panji Yudha \\ Universitas 17 Agustus 1945 Cirebon, Jln. Perjuangan No.17 Kota Cirebon, \\ rivoyudha@yahoo.co.id
}

\begin{abstract}
ABSTRAK
Penelitian ini bertujuan untuk melihat bagaimana implementasi pembelajaran Think Pair Share (TPS) dengan asesmen unjuk kerja berbantuan alat peraga materi geometri di SMP Negeri 1 Babakan. Desain penelitian eksperimen ini menggunakan Posttest-Only Control Design. Populasi dalam penelitian ini adalah seluruh siswa kelas VIII SMP Negeri 1 Babakan tahun ajaran 2016/2017. Dengan random sampling, sampel terpilih 34 siswa sebagai kelompok eksperimen dan 30 siswa sebagai kelompok kontrol. Metode pengumpulan data dalam penelitian ini menggunakan metode tes. Analisis data hasil belajar meliputi uji persyaratan analisis dan uji hipotesis. Uji persyaratan analisis berupa uji normalitas menggunakan uji Kolmogorov-Smirnov dan uji homogenitas menggunakan uji Levene. Uji hipotesis menggunakan uji z pihak kanan untuk menguji ketuntasan belajar siswa kelompok eksperimen dan uji t pihak kanan untuk menguji beda rata-rata antara kelompok eksperimen dan kelompok kontrol. Hasil uji ketuntasan belajar menunjukkan bahwa t hitung $=4,105$, sig 5\% $(1$ tailed $)=1.684$. Karena t tabel $<$ dari t hitung $(1.684<4.105)$, dan nilai sig. $0,000<0,05$ maka $\mathrm{H}_{1}$ diterima, artinya Persentase siswa yang tuntas lebih dari $75 \%$. Dari hasil uji kesamaan dua rata-rata diperoleh nilai Sig. (2-tailed) $=0,001<0,05$. Karena nilai sig. $<0,05$, maka $\mathrm{H}_{0}$ ditolak dan $\mathrm{H}_{1}$ diterima, hal ini menunjukan bahwa terdapat ata-rata nilai hasil belajar kelompok eksperimen lebih baik dibanding rata-rata nilai hasil belajar kelompok kontrol. Peneliti menyarankan bahwa waktu dalam menjalankan tiap fase dari pembelajaran TPS dengan asesmen unjuk kerja harus lebih efisien, dalam berdiskusi lebih dimaksimalkan pemanfaatan waktu agar tidak terlalu lama.
\end{abstract}

Kata kunci: Think Pair Share, Asesmen Unjuk Kerja

\section{ABSTRACT}

This study aims to examine how the implementation of Think Pair Share (TPS) learning with the performance assessment of geometric material aids at SMP Negeri 1 Babakan This experimental research design uses Posttest-Only Control Design. The population in this study is all students of class VIII SMP Negeri 1 Babakan year 2016/2017. With random sampling, selected sample of 34 students as experiment group and 30 students as 
control group. Methods of data collection in this study using the test method. Analysis of learning result data include test requirement analysis and hypothesis test. Test requirements analysis in the form of normality test using Kolmogorov-Smirnov test and homogeneity test using Levene test. Test the hypothesis using the right-handed z test to test the students' experimental study and experimental t test on the right side to test the average difference between the experimental group and the control group. The results of learning exhaustiveness test show that $t$ count $=4.105$, sig $5 \%(1$ tailed $)=1.684$. Because $t$ table <of $t$ count (1.684 <4.105), and sig value. 0,000 <0.05 then $H_{1}$ is accepted, meaning percentage of students who complete more than $75 \%$. From result of equality test of two mean obtained Sig value. $(2$-tailed $)=0.001<0.05$. Because the sig value. <0.05, then $H_{0}$ is rejected and $H_{1}$ accepted. The researchers suggest that the time in running each phase of the TPS learning with the performance assessment should be more efficient, in the discussion more maximized the utilization of time to not too long.

Keywords: Think Pair Share, Performance Assessment

How to Cite: Yudha, R. P. (2018). Implementasi Pembelajaran Think Pair Share dengan Asesmen Unjuk Kerja Berbantuan Alat Peraga Materi Geometri di SMP Negeri 1 Babakan. Mathline: Jurnal Matematika dan Pendidikan Matematika, Vol.3, No.1, 77-88.

\section{PENDAHULUAN}

Matematika mempunyai peran penting dalam berbagai disiplin ilmu serta dalam memajukan daya pikir manusia untuk menciptakan dan mengembangkan teknologi. Penguasaan matematika sangat diperlukan untuk menguasai dan menciptakan teknologi baru di masa mendatang. Matematika menjadi mata pelajaran yang dibutuhkan dan perlu dikuasai oleh siswa.

Mata pelajaran matematika perlu diberikan kepada semua siswa mulai dari sekolah dasar hingga perguruan tinggi untuk membekali siswa dengan kemampuan berpikir logis, analitis, sistematis, kritis dan kreatif, serta kemampuan untuk bekerjasama. Kompetensi tersebut diperlukan agar siswa dapat memiliki kemampuan memperoleh, mengelola, dan memanfaatkan informasi untuk bertahan hidup pada keadaan yang selalu berubah, tidak pasti, dan kompetitif (Depdiknas, 2006). Ini berarti bahwa tujuan umum pendidikan matematika adalah memberikan bekal kemampuan kepada siswa untuk dapat memecahkan masalah dalam kehidupan sehari-hari.

Menurut Zulkardi (Indrawati, 2016), dua masalah utama dalam pendidikan matematika di Indonesia adalah rendahnya prestasi siswa (rendahnya daya saing siswa diajang Internasional dan rendahnya nilai rata-rata UN murni nasional khususnya matematika) serta kurangnya minat mereka dalam belajar matematika (matematika dianggap sulit, menakutkan dan diajarkan dengan metode mencatat). Berdasarkan 
hasil analisis nilai UN 2016/2017 yang dilakukan oleh Depdiknas untuk penguasaan materi geometri bangun ruang untuk tingkat kota 44,31\%, tingkat provinsi 52,96\% dan 64,78\% tingkat nasional. Untuk itu perlu ada strategi untuk memecahkan masalah tersebut.

Hasil belajar siswa SMP Negeri 1 Babakan dikatakan tuntas belajar pada mata pelajaran matematika apabila telah memenuhi KKM (Kriteria Ketuntasan Minimal) klasikal dan KKM individual. Hasil belajar siswa SMP Negeri 1 Babakan dikatakan memenuhi KKM apabila sekurang-kurangnya75\% dari siswa yang berada pada kelas tersebut memperoleh nilai $\geq 75$. Nilai rata-rata ulangan harian kelas VIII materi bangun ruang pada tahun ajaran 2015/2016 adalah 65,75 dan tahun 2016/2017 adalah 65,014 .

Ketuntasan nilai ulangan matematika materi bangun ruang tahun 2015/2016 dan tahun 2016/2017 disajikan pada Tabel 1.1. Diduga pada tahun 2016 persentase ketuntasan masih sama.

Tabel 1 Persentase Ketuntasan tahun 2015/2016 dan 2016/2017

\begin{tabular}{lrr}
\hline Nilai & Tahun 2015/2016 & Tahun 2016/207 \\
\hline$<70$ & $55,63 \%$ & $57,55 \%$ \\
$\geq 70$ & $43,23 \%$ & $41,77 \%$ \\
\hline
\end{tabular}

Menurut salah satu guru matematika kelas VIII di SMP Negeri 1 Babakan, rendahnya hasil belajar siswa SMP Negeri 1 Babakan lebih terlihat khususnya pada materi yang bersifat abstrak, salah satunya yaitu pada materi geometri. Materi bangun ruang merupakan salah satu materi geometri di SMP kelas VIII. Materi ini mempunyai banyak aplikasi dalam kehidupan seharihari. Oleh karena itu, materi ini berkaitan erat dan sangat bermanfaat dalam kehidupan sehari-hari.

Berdasarkan hasil pengamatan dan wawancara yang dilakukan pada bulan Maret 2017, bahwa dalam kegiatan belajar mengajar matematika di SMP Negeri 1 Babakan selama ini, sebenarnya guru matematika sudah menerapkan pembelajaran berkelompok untuk menyampaikan konsep-konsep matematika. Namun apabila dicermati, kegiatan kelompok tersebut bukan pembelajaran kooperatif karena hanya didominasi oleh siswa yang pandai, sementara yang kemampuannya rendah kurang berperan.

Salah satu alternatif untuk mengatasi permasalahan tersebut, menurut Saad (2008), salah satu model pembelajaran yang dikenal dalam dunia pendidikan adalah model pembelajaran kooperatif yang membuat siswa bekerja sama dalam kelompok kecil untuk mencapai tujuan yang sama. Dalam model pembelajaran kooperatif, setiap anggota 
kelompok memiliki tanggung jawab dalam berpartisipasi sehingga dapat meningkatkan keterampilan sosial siswa. Think Pair Share (TPS) merupakan salah satu model pembelajaran kooperatif yang dapat digunakan untuk mendiskusikan suatu konsep matematika dengan prosedur berpikir, berpasangan (saling membantu) dan berbagi pendapat. Pemilihan dan pelaksanaan model pembelajaran yang tepat oleh guru akan membantu guru dalam menyampaikan pembelajaran matematika, sehingga siswa dapat memahami dengan jelas setiap materi yang disampaikan dan akhirnya mampu memecahkan setiap permasalahan yang muncul pada setiap materi yang dipelajarinya tersebut.

Pemakaian media pengajaran dalam proses belajar mengajar dapat membangkitkan keinginan dan minat yang baru, memotivasi dan merangsang kegiatan belajar, dan bahkan membawa pengaruh-pengaruh psikologis terhadap siswa (Arsyad, 2002). Dapat disimpulkan pemakaian media juga penting untuk merangsang dan memotivasi siswa dalam mengikuti proses pembelajaran. Kenyataan di lapangan, belum setiap kelas di SMP Negeri 1 Babakan dilengkapi dengan LCD proyektor dan jaringan internet juga masih sangat terbatas. Oleh karena itu, untuk mendukung pembelajaran yang lebih efektif dan menyenangkan, salah satu bentuk penggunaan media dalam proses pembelajaran yang dapat dipakai adalah penggunaan media alat peraga. Penggunaan alat peraga dapat menunjang pembelajaran di kelas. Selain itu adanya lembar kerja siswa dapat melatih kemandirian siswa dan mengaplikasikan pengetahuan baru yang mereka dapat melalui soal-soal.

Perlunya ada asesmen alternatif yang tidak hanya berupa tes tertulis (paper and pencil test). Salah satu tipe asesmen alternatif yang dapat digunakan adalah asesmen unjuk kerja. Dengan asesmen unjuk kerja siswa dituntut untuk menunjukkan bentuk kerja tentang apa yang mereka ketahui dan apa yang dapat mereka lakukan. Asesmen unjuk kerja dapat digunakan untuk membantu siswa membiasakan diri menunjukkan proses kerja dalam memahami dan memecahkan masalah. Dalam pembelajaran matematika asesmen unjuk kerja meliputi presentasi tugas matematika, proyek atau investigasi, observasi, wawancara (interview), dan melihat hasil (product) (Sa'dijah, 2009).

\section{METODE PENELITIAN}

Dalam penelitian ini jenis penelitian yang dilaksanakan adalah penelitian eksperimen. Desain penelitian eksperimen ini menggunakan Posttest-Only Control 
Design. Dalam desain penelitian ini terdapat dua kelompok yang dipilih secara acak. Kelompok pertama tidak memperoleh perlakuan khusus/ perlakuan biasa sebagai kelas kontrol $K$. Sedangkan kelompok yang kedua memperoleh perlakuan yang khusus sebagai kelas eksperimen $(E)$.

Siswa kelas VIII semester 2 SMP Negeri 1 Babakan tahun pelajaran 2016/2017 berjumlah 131 anak yang terdiri dari kelas VIII A sebanyak 34 anak, kelas VIII B sebanyak 32 anak, kelas VIII C sebanyak 34 anak, dan kelas VIII D sebanyak 30 anak. Jadi, populasi penelitian ini adalah seluruh siswa kelas VIII semester 2 SMP Negeri 1 Babakan tahun ajaran 2016/2017 yang terdapat pada kelas VIII A, VIII B, VIII C, dan VIII D. VIII A 34 VIII D.

Sampel dalam penelitian ini adalah dua kelompok siswa. Satu kelompok siswa tergabung dalam satu kelas eksperimen, yaitu kelas yang diberikan perlakuan berupa model pembelajaran TPS dengan asesmen unjuk kerja; dan satu kelompok siswa tergabung dalam satu kelas kontrol yang diberi perlakuan berupa pembelajaran yang sesuai dengan pembelajaran yang biasa guru gunakan yaitu Ceramah.

Pengambilan sampel dalam penelitian ini dilakukan secara random sampling. Hal ini dilakukan dengan pertimbangan bahwa kedudukan siswa dalam kelas diterapkan secara acak tanpa melihat peringkat nilai, jenis kelamin siswa, dan golongan siswa, sehingga siswa sudah tersebar secara acak dalam kelas yang ditentukan. Selain itu, banyaknya siswa dalam kelas relatif sama, siswa mendapat materi berdasarkan kurikulum yang sama, dan siswa mendapat waktu pelajaran yang sama. Sebelum penentukan dua kelompok sampel, peneliti telah menguji data awal hasil belajar siswa berupa nilai Ulangan Tengah Semester Genap. Dari hasil uji statistik tersebut dapat disimpulkan bahwa populasi berdistribusi normal dan memiliki varians yang sama. Berdasarkan teknik random sampling dalam penelitian ini, terpilih siswa kelas VIII A dan siswa VIII D. Siswa kelas VIII A sebagai kelompok kontrol dengan 34 siswa, dan siswa kelas VIII D sebagai kelompok eksperimen dengan 30 siswa.

Instrumen penelitian meliputi perangkat pembelajaran dan instrumen pengumpulan data. Perangkat pembelajaran meliputi meliputi Silabus, RPP, Tes uraian. Instrumen pengumpulan data yang diperlukan pada penelitian ini meliputi catatan lapangan untuk memperoleh data awal, lembar keterlaksanaan pembelajaran TPS, lembar observasi aktivitas siswa.

Teknik analisis data untuk uji data ketuntasan hasil belajar (Uji Z). Uji z dilakukan untuk menguji hipotesis I untuk mengetahui apakah hasil belajar siswa 
pada materi prisma dan limas dengan model pembelajaran TPS dengan asesmen unjuk kerja dapat mencapai ketuntasan klasikal. Kriteria ketuntasan yaitu persentase siswa yang mencapai ketuntasan individu minimal sebesar $75 \%$. Uji hipotesis ketuntasan klasikal menggunakan uji proporsi satu pihak yaitu pihak kiri. Uji Hipotesis II dilakukan untuk mengetahui ada atau tidaknya perbedaan rata-rata antara kelas eksperimen dan kelas kontrol yang keduanya tidak saling berhubungan.

\section{HASIL DAN PEMBAHASAN}

\section{Hasil Pembelajaran Model Think Pair Share dengan Asesmen Unjuk Kerja}

Pembelajaran pada kelompok eksperimen dilaksanakan dalam tiga kali pertemuan (enam jam pelajaran). Satu jam pelajaran berlangsung selama 40 menit. Pertemuan pertama dilaksanakan pada hari Rabu tanggal 22 Mei 2013 jam ke 1-2 dengan materi yang dipelajari adalah luas permukaan dan volum prisma. Pertemuan kedua dilaksanakan pada hari Jumat tanggal 24 Mei 2013 jam ke 1-2 dengan materi yang dipelajari adalah luas permukaan dan volum limas. Pertemuan ketiga dilaksanakan pada hari Rabu tanggal 29 Mei 2013 jam ke 1-2 dengan kegiatan pembelajaran berupa latihan soal materi luas permukaan dan volum prisma dan limas.

Tes diberikan setelah proses pembelajaran selesai dilaksanakan, Nilai tertinggi pada kelompok eksperimen adalah 100, terendah 58, dan varians 128,492. Nilai tertinggi pada kelompok kontrol adalah 96, terendah 54, dan varians 122,007. Setelah pelaksanaan tes hasil belajar, nilai dari hasil belajar tersebut dianalisis. Rata-rata nilai hasil belajar pada kelompok eksperimen adalah 80 dan rata-rata nilai hasil belajar pada kelompok kontrol adalah 74. Analisis data hasil belajar meliputi uji persyaratan analisis dan uji hipotesis.

\section{Uji Persyaratan Analisis}

\section{Uji Normalitas}

Pada perhitungan uji Kolmogorov-Smirnov, diperoleh nilai uji Kolmogrov $=$ 0,081, dan 0,076. Nilai Dtabel untuk ukuran sampel 34 dan $\alpha=5 \%$. Berdasarkan perhitungan, nilai hitung untuk kedua kelompok sampel lebih dari 0, 05 (5\%), maka $\mathrm{H}_{0}$ diterima sehingga data nilai hasil belajar untuk kelompok eksperimen dan kelompok kontrol berasal dari populasi yang berdistribusi normal. 
Tabel 2 Test of Normality

\begin{tabular}{lrrrr}
\hline \multicolumn{5}{c}{ Kolmogorov-Smirnov } \\
& Statistic & df & Shapiro-Wilk & Statistic df Sig. \\
\hline Kelas Eksperimen & .147 & 34 & .081 & .82334 .000 \\
Kelas Kontrol & .143 & 34 & .076 & .94434 .083 \\
a. Lilliefors Significance Correction & & \\
\hline
\end{tabular}

\section{Uji Homogenitas}

Dari hasil di atas dapat diketahui signifikansi sebesar 0,882. Karena signifikansi lebih dari 0,05 maka dapat disimpulkan bahwa kedua kelompok data TPS siswa berdasar asesmen unjuk kerja mempunyai varian sama. Angka Levene Statistic menunjukkan semakin kecil nilainya maka semakin besar homogenitasnya. df1 = jumlah kelompok data1 atau 2-1=1 sedangkan df $2=$ jumlah data - jumlah kelompok data atau 34-1=33.

Tabel 3 Test of Homogenity of Variances

\begin{tabular}{rrrrr}
\hline $\begin{array}{l}\text { Levene } \\
\text { Statistic }\end{array}$ & df1 & & df2 & \multicolumn{1}{c}{ Sig. } \\
\hline .022 & 1 & 33 & .882 \\
\hline
\end{tabular}

\section{Uji Hipotesis I (Uji Ketuntasan Belajar)}

Pada perhitungan hasil belajar siswa dari 34 siswa pada kelompok eksperimen terdapat 30 siswa yang tuntas. Sekolah menetapkan KKM klasikal sebesar $75 \%$. Dengan menggunakan SPSS v16. Maka diperoleh hasil berikut.

Tabel 4 One-Sample Statistics

\begin{tabular}{|c|c|c|}
\hline \multicolumn{3}{|c|}{ N Mean Std. Deviation Std. Error Mean } \\
\hline Postes Eksperimen 3479.24 & 6.015 & 1.032 \\
\hline
\end{tabular}


Tabel 5 One-Sample Test

\section{Test Value $=75$}

\begin{tabular}{|c|c|c|c|c|c|}
\hline & \multirow[b]{3}{*}{$\mathbf{T}$} & \multirow{3}{*}{$\begin{array}{l}\text { Sig. (2- } \\
\text { tailed) }\end{array}$} & \multirow{3}{*}{$\begin{array}{c}\text { Mean } \\
\text { Difference }\end{array}$} & \multicolumn{2}{|c|}{ 95\% Confidence Interval of the } \\
\hline & & & & Diffe & \\
\hline & & & & Lower & Upper \\
\hline $\begin{array}{l}\text { Postes } \\
\text { Eksperimen }\end{array}$ & 4.10533 & .000 & 4.235 & 2.14 & 6.33 \\
\hline
\end{tabular}

Hasil uji di atas menunjukkan bahwa t hitung $=4,105$. $\mathrm{T}$ tabel diperoleh dengan $\mathrm{df}$ $=33$, sig 5\% $(1$ tailed $)=1.684$. Karena $t$ tabel $<$ dari t hitung $(1.684<4.105)$, dan nilai sig. $0,000<0,05$ maka $\mathrm{H}_{1}$ diterima, artinya Persentase siswa yang tuntas lebih dari $75 \%$.

\section{Uji Hipotesis II (Uji Kesamaan Dua Rata-rata)}

Dari hasil uji $\mathrm{T}$ (tabel) diatas diperoleh nilai Sig. (2-tailed) $=0,001<0,05$. Karena nilai signifikansi $<0,05$, maka $\mathrm{H}_{0}$ ditolak dan $\mathrm{H}_{1}$ diterima, hal ini menunjukan bahwa terdapat ata-rata nilai hasil belajar kelompok eksperimen lebih baik dibanding rata-rata nilai hasil belajar kelompok kontrol.

Tabel 6 Independent Samples Test

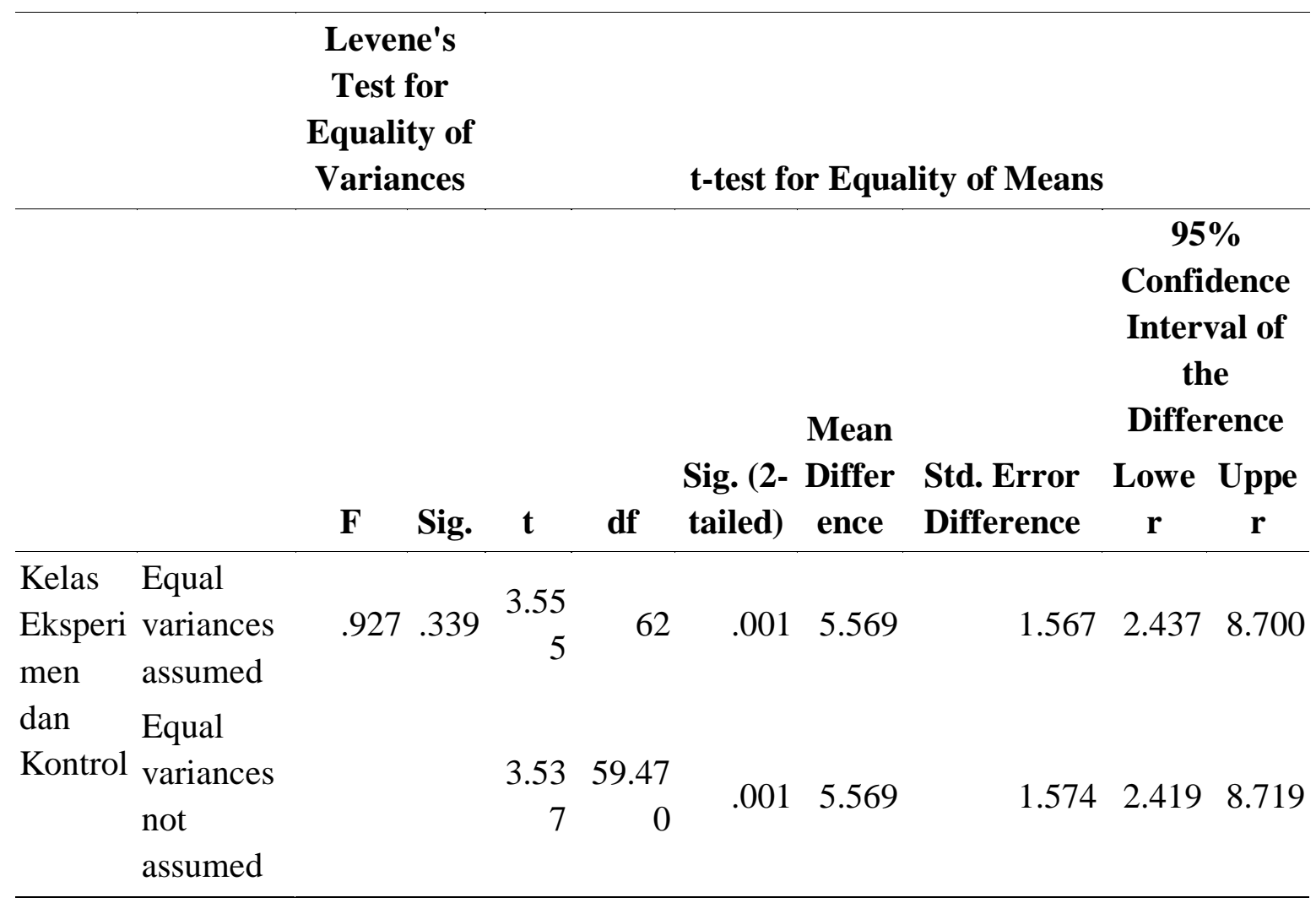




\section{Ketuntasan Belajar Kelas Eksperimen}

Berdasarkan hasil pengujian hipotesis pertama mengenai ketuntasan belajar secara klasikal dapat disimpulkan bahwa pembelajaran menggunakan model TPS dengan asesmen unjuk kerja terhadap hasil belajar siswa SMP Negeri 1 Babakan mencapai ketuntasan belajar klasikal yang ditetapkan oleh sekolah sebesar 75\%. Banyaknya siswa dari 34 siswa pada kelompok eksperimen yang memperoleh nilai hasil belajar mencapai 75 adalah 30 siswa.

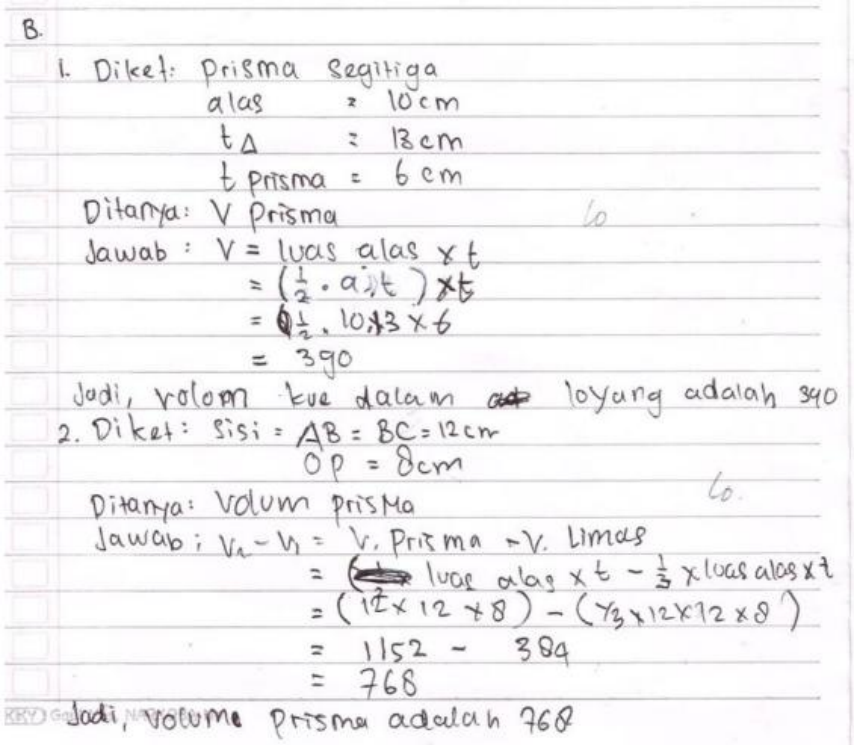

Gambar 1 Hasil Pekerjaan Siswa

Dari hasil tes hasil belajar salah satu siswa pada kelas eksperimen yang memperoleh pembelajaran TPS dengan asesmen unjuk kerja pada Gambar 1 terlihat bahwa siswa mengerjakan soal dengan benar. Hal ini sejalan dengan pendapat Masrukan (2013), bahwa kecocokan kombinasi model pembelajaran kooperatif dan asesmen kinerja menurut Polya terlihat dari langkah-langkah penyelesaian masalah yang disarankan, yaitu: (1) memahami masalah; (2) merencanakan penyelesaian; (3) melaksanakan rencana/perhitungan; dan (4) memeriksa kembali proses dan hasil. Dengan bekerja dalam kelompok kecil keempat langkah tersebut dilakukan secara bersama-sama. Kecermatan dan ketelitian dalam menyelesaikan permasalahan matematika akan dikontrol oleh seluruh anggota kelompok. Hal ini jelas lebih baik dibandingkan dengan dilakukan hanya oleh seseorang.

Kemudian berdasarkan lembar observasi kualitas pembelajaran yang digunakan untuk mengamati kualitas pembelajaran TPS dengan asesmen unjuk kerja pada kelas eksperimen selama tiga kali pertemuan oleh pengamat yaitu guru mata pelajaran matematika disekolah penelitian diperoleh skor rata-rata baik, begitu pula untuk 
pengamatan keaktifan siswa diperoleh skor rata-rata aktif, serta pengamatan kinerja guru diperoleh skor rata-rata baik. Hal tersebut menunjukkan bahwa pembelajaran TPS dengan asesmen unjuk kerja mencapai ketuntasan belajar pada hasil belajar materi prisma dan limas.

\section{Perbandingan Hasil Belajar Kelompok Eksperimen Dan Kontrol}

Berdasarkan hasil pengujian hipotesis kedua mengenai penerapan model pembelajaran dapat disimpulkan bahwa rata-rata hasil belajar siswa pada kelompok eksperimen dengan model pembelajaran TPS dengan asesmen unjuk kerja lebih baik daripada rata-rata hasil belajar siswa pada kelompok kontrol dengan ceramah. Lebih tingginya rata-rata hasil belajar siswa pada kelompok eksperimen dibanding dengan rata-rata hasil belajar siswa pada kelompok kontrol dikarenakan dalam pembelajaran dengan model TPS dengan asesmen unjuk kerja materi disajikan dengan menarik sehingga mampu menggugah minat belajar siswa. Hal ini dikarenakan pada pembelajaran eksperimen siswa bekerja secara kelompok untuk menemukan rumus luas permukaan dan volum prisma dan limas, serta penggunaannya dalam menyelesaikan masalah dengan bantuan asesmen unjuk kerja berupa penilaian unjuk kerja dan LKS. Pertanyaanpertanyaan untuk mengkonstruk pengetahuan siswa dituangkan dalam LKS yang harus dikerjakan oleh setiap kelompok.

Pada pertemuan pertama kelas eksperimen siswa membuat jaringjaring prisma yang diukur panjang, lebar, dan tingginya, masing-masing data prisma digunakan untuk menemukan rumus luas permukaan prisma, masingmasing data ditulis pada LKS. Dengan data panjang, lebar, dan tinggi prisma, siswa mendapatkan rumus luas permukaan prisma. Selanjutnya pada pertemuan kedua kelompok eksperimen dengan langkah yang sama siswa menemukan rumus luas permukaan limas. Jadi siswa pada kelompok eksperimen menemukan konsep rumus luas permukaan prisma dan limas dengan cara mengerjakan tugas unjuk kerja dan menjawab pertanyaan-pertanyaan yang terdapat pada LKS bersama teman-teman sekelompoknya sebagai bekal untuk mengerjakan soal yang diberikan pada halaman terakhir pada LKS. Hal ini membuat siswa pada kelompok eksperimen mengembangkan kreativitasnya dalam membuat tugas unjuk kerja dan menjawab pertanyaan-pertanyaan yang mengkonstruk pengetahuan siswa yang ada di LKS dengan antusias.

Penggunaan media juga mencakup segala potensi belajar siswa. Penggunaan alat peraga membantu siswa dengan potensi belajar visual sehingga mereka dapat melihat secara langsung visualisasi bagaimana rumus luas permukaan serta volum prisma dan 
limas diperoleh. Selain itu, penggunaan alat peraga mampu memenuhi kebutuhan siswa kinestetik yang selalu ingin melakukan pengetahuan-pengetahuan baru yang mereka peroleh sehingga pengetahuan baru tersebut dapat melekat pada pemikiran mereka. Hal tersebut sesuai dengan pendapat Bruner yang menyatakan bahwa dengan adanya benda yang secara langsung dapat siswa amati, sentuh dan manipulasi dapat membantu siswa memahami struktur dan pola benda tersebut. Untuk siswa dengan potensi belajar audio, mereka merekam dalam otak mereka apa yang dijelaskan oleh guru dan menanyakan apa yang mereka kurang pahami serta menjawab pertanyaanpertanyaan yang diberikan oleh guru.

Selain itu, penggunaan lembar kerja siswa juga membantu dalam proses pembelajaran yaitu adanya langkah-langkah kerja yang membantu siswa memahami materi baru serta adanya latihan soal yang membantu mereka untuk mengaplikasikan pengetahuan baru yang mereka dapat melalui soal-soal. Rata-rata nilai hasil belajar siswa pada kelompok eksperimen lebih tinggi dibanding rata-rata nilai hasil belajar siswa pada kelompok kontrol, hal ini disebabkan pembelajaran akan lebih bermakna apabila anak aktif dalam pembelajaran, anak dapat berinteraksi dengan siswa lain, dan anak memperoleh pengetahuan baru melalui pengalamannya sendiri. Dalam proses pembelajaran dengan model TPS siswa diberi kesempatan untuk aktif selama pembelajaran berlangsung.

Dengan adanya asesmen unjuk kerja yang memberikan siswa unjuk kerja dalam proses pembelajaran sehingga siswa menjadi aktif baik dengan mengajukan pertanyaan, melakukan tugas unjuk kerja atau dengan memanipulasi alat peraga yang disediakan. Selain itu, siswa juga diperbolehkan untuk berdiskusi mengenai materi baru yang mereka peroleh dengan siswa lain misalnya saat mengerjakan soal-soal latihan. Dengan berinteraksi siswa dapat bertukar pikiran dan membantu perkembangan kognitif siswa. Siswa juga belajar melalui pengalaman mereka sendiri. Siswa memanipulasi alat peraga yang disediakan dan berdiskusi mengerjakan tugas unjuk kerja siswa untuk menentukan rumus luas permukaan serta volum prisma dan limas. Pengalaman sendiri yang dialami siswa mampu membentuk pembelajaran yang bermakna dan pengetahuan akan selalu menempel pada ingatan siswa.

Dalam pembelajaran TPS dengan asesmen unjuk kerja tidak banyak kendala yang ditemui. Akan tetapi, tidak banyak orang yang mampu mengkombinasikan asesmen unjuk kerja dan alat peraga dalam pembelajaran yang menarik. Mereka yang hanya menggunakan satu gaya belajar cenderung hanya akan mampu menangkap materi jika 
menggunakan metode yang lebih memfokuskan kepada salah satu gaya belajar yang didominasi.

Mengetahui gaya belajar masing-masing siswa dapat membantu dan bermanfaat bagi siswa menjadi lebih fokus dan perhatian sehingga dapat meningkatkan kesuksesan belajar. Selain itu siswa juga dapat mengasah daya kreatif dan penalaran mereka, misalnya dalam memanipulasi alat peraga yang ada serta dalam mengerjakan soalsoal latihan dalam lembar kerja siswa. Meningkatnya kemampuan berpikir kreatif berbanding lurus dengan meningkatnya hasil belajar siswa, sehingga apabila model pembelajaran TPS diterapkan dalam pembelajaran maka akan memberikan efek positif terhadap hasil belajar siswa.

\section{KESIMPULAN}

Penerapan model pembelajaran TPS dengan asesmen unjuk kerja terhadap hasil belajar siswa SMP Negeri 1 Babakan pada materi prisma dan limas mencapai ketuntasan belajar secara klasikal; Rata-rata hasil belajar siswa SMP Negeri 1 Babakan pada materi prisma dan limas dengan penerapan model pembelajaran TPS dengan Asesmen unjuk kerja lebih baik dari rata-rata hasil belajar siswa dengan Ceramah.

\section{DAFTAR PUSTAKA}

Arsyad, A. (2002). Media Pembelajaran. Jakarta: Raja Grafindo Persada.

Depdiknas. (2006). Petunjuk Teknis Pengembangan Silabus dan Contoh/Model Silabus SMA/MA Matematika. Jakarta: BSNP.

Indrawati. (2016). Penerapan Model Pembelajaran Talking Stick dengan Media LKS dalam Peningkatan Motivasi dan Prestasi Belajar Matematika Siswa SD Negeri Girireja Kecamatan Ngombol Kabupaten Purwerojo Tahun Pelajaran 2013/2014. Jurnal Pendidikan Universitas Muhamadiyah, 8 (1), 1-12.

Masrukan. (2013). Asesmen Otentik Pembelajaran Matematika. Semarang: Swadaya Manunggal.

Saad, N. S. (2008). Teaching Mathematics in Secondary Schools: Theories and Practices. Perak: Universiti Pendidikan Sultan Idris.

Sa'dijah, C. (2009). Asesmen Kinerja dalam Pembelajaran Matematika. Jurnal Pendidikan Inovatif, 4(2): 92-95. 